\title{
Taking Without Paying: Interpreting Property Rights in Australia's Constitution
}

\author{
John Forbes
}

$\mathrm{H}$ igh Court judgments now abound with liberal interpretations, not to mention fundamental changes to public and private law. But when it comes to making the Commonwealth pay for fashionable interference with rights of property, the Court displays a curious conservatism.

Questions about compensation for governmental interference with property are many and complex. This article makes no pretence of covering the field. That would require a weighty tome, because incursions on property rights are made by a host of Commonwealth Acts, State laws and local government ordinances.

Many different opinions are held about the adequacy of existing compensation rights. Should they cover consequential losses as well as the immediate value of the property taken - relocation expenses, replacement costs, a solatium for physical or psychological disturbance? On the parsimonious side, it is said that personal and psychological factors are intangible, infinitely variable and essentially non-compensable. Yet similar losses are regularly compensated by the courts in personal-injury cases.

Compensation for 'injurious affection' is a more difficult issue. That expression refers to acts of government that do not directly or formally touch the property in question, but which nevertheless damage its value and enjoyment. Examples include airport extensions which affect residential areas, conversions of suburban streets into highways, and the erection of high-tension electricity lines without resumption of the property concerned. The common refusal to pay compensation for injurious affection is not based upon any clear theoretical distinction between adverse 'affection' and resumption, but upon financial expediency. The courts, once again, regularly assess damages for similar intangibles and imponderables, as with unliquidated (i.e. 'guesstimated', not mathematically calculated) damages for the tort of private nuisance.

This article considers a compensation problem which is nearer the middle of the spectrum than 'injurious affection', namely, the de facto resumptions (partial and sometimes near-complete) that occur when governments unilaterally impose controls on the use of land under the rubrics of 'environment', 'heritage values' and the like. Rights to compensation in these cases are uncertain and the increasingly urgent question of what they should be has not been adequately examined. 


\section{Eminent Domain}

The principle upon which all governmental acquisitions are based is the Crown's right of 'eminent domain' - the axiomatic power of governments to take private property for public purposes. There is no constitutional right to property in Australian law; ownership, like free speech and the right of assembly, is a residual right that waxes or wanes according to the restrictions which federal and State laws place upon it.

The Commonwealth and the States do have acquisition acts which set out general procedures for the resumption of property and the payment of compensation. But these laws have no special constitutional status; they are ordinary legislation that can be repealed or amended at any time by a bare parliamentary majority. Only tradition and public opinion prevent the States from resuming property without compensation; and occasionally those inhibitions are cast aside. Since 1900 several Australian States have simply confiscated private rights to petroleum or to minerals - rights originally granted by them to early freeholders. As recently as 1981 New South Wales passed a Coal Acquisition Act which abolished all private ownership of coal deposits in the State. (Some ex gratia compensation was grudgingly paid several years later.)

Only the Commonwealth has a constitutional duty to pay 'just terms' for property that it compulsorily acquires. In 1988 a proposal of the Hawke Labor Government to extend the 'just terms' guarantee to State constitutions was rejected at a national referendum. However, even if an all-Australian 'just terms' clause had come to pass it may not have been so efficacious as it supporters expected. In the hands of the High Court the Commonwealth's own constitutional 'guarantee' is proving, under modern conditions, to be an insurance policy with some disconcerting exclusion clauses.

According to the doctrine of eminent domain, the giving of reasonable notice and the payment of proper compensation are left to political morality and gentlemanly understandings. But it appears that the Founding Fathers were not prepared to trust their child, the Commonwealth, to that extent. They embedded the traditional understanding in Section 51(xxxi) of the Constitution:

The Parliament shall ... have power to make laws for the peace, order, and good government of the Commonwealth with respect to ... a acquisition of property on just terms from any State or person for any purpose in respect of which the Parliament has power to make laws.

In 1979 Chief Justice Barwick described this provision as a 'very great constitutional safeguard'. But until the term 'acquisition' is more liberally and realistically interpreted that statement will have more than a touch of hyperbole.

\section{'Just Terms'}

In the 'just terms' clause there are three elements: property; acquisition; and proper compensation. A great deal of ink has been spilt on all three but at this stage of our constitutional history, and in the light of the Commonwealth's rapidly increasing intervention in land-use law - once very largely a State concern - the 'acquisition' con- 
cept needs especially close attention. 'Property' and 'just terms' are already quite liberally interpreted. 'Property' covers leaseholds as well as freeholds. It is not confined to land: it includes intangibles such as copyright and other intellectual property. In 1982 it was said that "in modern legal systems "property" embraces every possible interest recognised by law which a person can have in anything and includes practically all valuable rights. In a recent case relating to the Timor Gap treaty between Australia and Indonesia, 'property', as a constitutional term, was extended to oil exploration licences which were cancelled by the Commonwealth when the treaty came into being.

However, the 'just terms' clause is no stronger than its weakest link and 'acquisition' is interpreted narrowly. The significance of this restriction is growing rapidly. The narrowness probably did not matter much when acquisitions by the Commonwealth were relatively straightforward and traditional affairs. Until the 1970s land-use law in Australia was largely a State concern. The Commonwealth intervened only now and then to acquire land for purposes such as defence, communications and aviation. It had not yet thought of imposing land-use controls in the name of the environment, 'heritage', 'national estate' or Aboriginal affairs, relying on the High Court's recent and generous interpretations of the 'external affairs' power (Constitution s.51 $(\mathrm{xxix}))^{3}$ and the 'race' power (s.51 (xxvi)). (There is neither space nor need to detail such legislation here; the interested reader may refer to the Australian Heritage Commission Act 1975, the National Parks and Wildlife Conservation Act 1975, the World Heritage Properties Conservation Act 1983 and the Aboriginal and Torres Strait Islander Heritage Protection Act 1984.) Sometimes, instead of relying on overt legislation of this kind, the Commonwealth uses its power to refuse export permits to render State-approved developments worthless.

It emerges from the Tasmanian Dam case (1983) that Commonwealth environmental policies can virtually 'sterilise' State or private land without bringing into play the duty to pay 'just terms', provided that the legal title is left in the name of the owner affected. This is so because the current judicial meaning of 'acquisition' is wedded to old technicalities of private land law. According to this school of thought there is no 'acquisition' unless the Commonwealth takes an outright conveyance of property and formally places the title in its own name. Thus the meaning of 'acquisition' remains incongruously narrow and formalistic while judicial creativity, not to mention the occasional legal revolution, flourishes in other High Court jurisprudence. Government intervention in the name of the environment, aboriginal rights, 'heritage values' and so on - intervention which is often election-driven and difficult to predict - is now

\footnotetext{
'Doman v Rogers (1982) 148 CLR 365 at 372.

2

Westem Mining v The Commonwealth (1994) 121 AlR 661 (appeal pending).

3

Tasmaujan Dam Case (1983) 158 CLR 1.

${ }^{4}$ As in Muphyores Inconporated Pty Ld v Commonwealth (1976) 136 CIR 1 (sand mining leases on Fraser Island). The system of export permits underpins the federal government's 'three mines' policy on uranium.
} 
such that the value of property can be destroyed or greatly diminished without compensation so long as title or possession has not been taken, in the parlance of the cottage conveyancer.

This approach is questionable on technical as well as philosophical grounds. In legal theory 'property' is not the physical object (if indeed there be a physical object) to which the rights of ownership are attached. It refers to the rights themselves. Those rights are better thought of as a 'bundle' of entitlements: rights of entry, rights to exclude others, rights to cultivate, to build, and so on. If, for example, I lease my land to another person I have lost - for the duration of the lease - the right to occupy and to use that land. For the time being I am deprived of several items in my bundle of property rights. I retain the reversion (the right to resume full ownership when the lease ends) and in the meantime I may have limited rights of entry and inspection. But the rest of the bundle is in the tenant's hands.

Similarly, when government removes or diminishes rights to property without assuming full ownership it should be seen as 'acquiring' a proportionate number of the rights in the proprietary 'bundle'. The reasons for adopting this more flexible and more realistic approach are all the stronger when (as here) we are talking of 'acquisition' in the context of a Constitution, a set of fundamental principles which govern the making of federal laws. It is a High Court truism (never more so than today) that the Commonwealth Constitution is to be interpreted more liberally than the words of a land sale contract, a mortgage deed or a consignment note. The mantra of 'liberal construction' has been invoked to give the Commonwealth far greater powers with respect to taxation, 'trade and commerce', offshore resources and company law than were dreamt of 50 years ago. More recent, not to say spectacular, is the extremely wide interpretation of the previously modest 'external affairs' power since 1983. This development alone has probably enabled the Commonwealth, equipped itself with a suitable treaty or 'international concern', to take over any legislative power of the States whether or not it is mentioned in any other part of the Constitution. Given a plausible 'external affair', the question is no longer: 'Can the Commonwealth legally do such-and-such?' but rather: 'Does the Commonwealth want to do it?'

Having paved the legal path to a unitary State, the High Court — appointed entirely by federal cabinet or its advisers - has now turned to the discovery of 'implied' bill of rights provisions in the federal Constitution ${ }^{7}$ and even in a State Constitution. While these legislative activities of the Court may be seen by its members as based on

\footnotetext{
5 Mutual Pools \& Stall Pty Ltd v The Commonwealth (1994) 68 AIJR 216. 6 Tasmania v The Commonwealth (1983) 158 CLR 1.

7

Nationwide News (1991) 177 CLR 1 (free speech about industrial courts); Theophanous (1994) 68 ALJR 713 (ditto regarding politicians, State as well as federal); ACT Television (1992) 177 CLR 106 (political advertising). See also Moens \& Trone (1994).

8

Stephens (1994) 68 AIJR 765.
} 
intuitions of 'contemporary values', ${ }^{9}$ it may be remembered that so recently as 1988 Australians emphatically voted 'no' at a referendum which included several 'Bill of Rights' issues. The one impermissible implication, it almost seems, is that the Constitution is a federal compact. This impression is not dispelled when the occasional crumb of consolation is given to the States, such as allowing Victoria to maintain its own public service but not to set the salaries and conditions of their employment, ${ }^{10}$ or striking down Western Australia's native title laws and finding one small and insignificant flaw in the Commonwealth Act.

Nor is the High Court averse to unsettling or extending the rules of private law. In one of the most recent exercises of its legislative jurisdiction the Court made a contribution to solving the problem of gross over-expansion of our law schools by creating a new rule which allows second, third and even fourth-hand owners of homes (and presumably commercial premises as well) to sue the builder for alleged defects in materials or the construction work.

The present question is not whether these novel decisions are wise, or within the proper limits of judicial power. The point here is that when decisions of this breadth are being taken the High Court's restrictive approach to 'acquisition' is a prime example of straining at a gnat.

\section{'Acquisition' in the Tasmanian Dam Case}

It is a curious irony that the 'cottage conveyancing' approach to the 'just terms' clause was reasserted in the very case that practically converts the 'external affairs' power into a plenary legislative power. In the Tasmanian Dam case the Commonwealth, in the name of international obligations (and in hot pursuit of immediate political advantages) effectively 'sterilised' a large area of south-west Tasmania, the property of the State and its agencies. Thenceforth there could be no development of the land without the Commonwealth's pernission. This article does not seek to re-argue the political, social or even the legal merits of that action. Our present concern is the sharp contrast between the Court's liberal interpretation of the external affairs power (which benefited the Commonwealth) and its narrow, formalistic interpretation of 'acquisition' (which also favoured the Commonwealth). A wide meaning was given to words which suited the Commonwealth and a 19th-century, black-letter approach was taken to one word that would have given some solace to the property owner.

\footnotetext{
${ }^{9}$ See for example Mabo $v$ Queenslaud (No 2) (1992) 175 CLR 1 at 30 per Bremnan J. Mabo is not a constitutional decision in the strict sense but it seems reasonable to suppose that judges who consider that they can read the community's conscience in one area of the law retain that confidence in other areas. 10

Victoria v Commonweald, High Court 7 April 1995 (application of Commonwealth industrial awands to State employees).

11

Westen Australia v The Commonwealth (1995) 68 ALJR 309. (Commonwealth may not make the common law of native title 'a law of the Commonwealth', but the High Court remains free to declare and to interpret that new-found common law.)
}

12

Maloney v Bryau, 23 March 1995; see The Austalian, 24 March 1995, p.3. 
Justice Mason, the senior judge in a majority of 4 to 3 , dismissed the plea for a realistic definition of 'acquisition' as follows:

Tasmania's submission is that, although the Act does not attempt to divest tithe from the State .. it so restricts lits] rights ... that there has been an acquisition of property ... [But] to bring the constitutional provision into play it is not enough that legislation adversely affects or terminates a pre-existing right that an owner enjoys in relation to his property; there must be an acquisition whereby the Commonwealth or another acquires an interest in property . .

Justice Mason conceded the State's claim that its property had been 'sterilised', but that was beside the point:

[W] hat is important in the present context is that neither the Commonwealth nor anyone else acquires . . . a proprietary interest of any kind ... The [sterilisingl power of the Minister . . . is merely a powerful veto. He cannot positively authorise the doing of acts on the property ... the State remains in all respects the owner...

Laymen too readily accept lawyers' value-judgments presented as professional and technical mysteries. Without the guidance of the High Court ordinary citizens might be forgiven for thinking that, when the government leaves a landowner holding the title deed but forbids him to use 'his' land without its permission, he is no longer 'in all respects' the owner.

Justice Murphy, a champion of broad constitutional interpretation, momentarily became a black-letter property lawyer when faced with Tasmania's claim that if the Commonwealth controls were valid (which it denied) then at least compensation must be paid. (Did it cross the majority's mind that, in that event, the price of the Commonwealth's fireworks display might be prohibitive?) Justice Murphy simply asserted that 'the extinction or limitation of property rights does not amount to acquisition' and that, for all the talk at other times about the 'spirit' of the Constitution, there was no 'acquisition'.

Justice Brennan, too, was dismissive: 'The free enjoyment of proprietary rights . . . may be affected by a great variety of laws, but [s.51 (xxxi)] extends only to laws for the acquisition of proprietary rights ... [So] the question of just terms does not arise. ${ }^{16}$ However, one judge in the majority - Justice Deane - recalled that a distinguished former Chief Justice, Sir Owen Dixon, had said some 35 years earlier that the just terms' guarantee is 'not to be confined pedantically to the taking of title . . . but ...

\footnotetext{
${ }^{13}$ Tasmanian Dam Case (1983) 158 CLR at 144-5, emphasis added. 
extends to innominate and anomalous interests'. 17 Deane J was inclined to think that when intervention approaches 'sterilisation' the difference of degree becomes a difference of kind. If the Court continued to force the 'just terms' guarantee into the pigeonhole of ordinary conveyancing law the Commonwealth could make a mockery of s.51 (xxxi) provided that it left the title deeds in the hands of the 'owner':

The Commonwealth has, by the Wilderness Regulations, brought about a position where the HEC land is effectively frozen ... If there were any reason in principle which prevented ... [that from being] an acquisition of property, the safeguard of s.51(xxxi) would be ineffective to preclude the Commonwealth from ... dedicating the property of others to its [own] purposes without compensation . . . by the imposition of carefully-worded restrictions. . .

Besides, even if private law technicalities had to be adhered to, Deane J thought that the present case called for 'just terms'. In his opinion, the Commonwealth's banning of the Franklin Dam development was akin to a 'restrictive covenant', such as a legally enforceable promise that a landowner who subdivides an old property may impose on new neighbours to ensure (for example) that they do not erect buildings which spoil his scenic views. And he who takes a restrictive covenant acquires a species of property right.

\section{Acquisition and Regulation}

If we are to have broader and broader interpretations of the Commonwealth Constitution, it should not matter whether they suit the central government or not. If a realistic interpretation of 'acquisition' makes federal vote-catching more expensive, and leads politicians and their advisers to count more carefully the costs of 'government by pressure group', then the public interest, on balance, may be served.

The main defence of the narrow meaning of 'acquisition' is that a more liberal approach would raise difficult questions of degree, not to mention claims upon the federal Treasury that may be so large as to force interventionist politicians and bureaucrats to think again. When would reasonable regulation of property rights become an 'acquisition'? At first glance this may seem a sage objection, but it is really an evasive counsel of despair. In truth, the law is already replete with questions of degree; on many issues of damages and compensation the courts are left to draw a line according to the evidence and every day they do so. For example: Where does reasonable care begin and end? When is the harm caused by an alleged nuisance unreasonably out of keeping with any benefits flowing from the action in question, and the character of the neighbourhood? When does a trade restraint become 'unreasonably' tilted against the interests of the person restrained, or the public interest? And in the constitutional arena: When is an exercise of the 'defence power' proportionate to the

\footnotetext{
${ }^{17}$ Bank of New South Wales v The Commonwealth (1948) 76 CLR 1 at 349 per Dixon J. 18 
current needs of national security? When are administrative arrangements 'reasonably incidental' to one of the Commonwealth's 'heads of power'? Similarly, if a more flexible approach were taken to 'acquisition' as opposed to 'regulation', there would be borderline cases upon which reasonable minds might differ, but the same counsel of despair (or inertia) can be applied to many other areas of private and public law.

The task of nominating the point at which regulation shades into acquisition is not a peculiarly Australian problem. The American courts have also had to deal with questions of when official (or officious) controls become a 'taking' of property within the meaning of the Fifth Amendment to the Constitution of the United States. The US Supreme Court has not found it necessary to insist that a resumption or 'taking' less than 100 per cent is not an acquisition. Cases of alleged 'taking' without 'just compensation' are decided upon the particular facts (Walters, 1994).

In a small way, perhaps, some Australian States have found a way of compensating owners of premises placed on 'heritage' registers. An owner of such a property may reasonably ask why he should have to bear the expense, in maintenance and capital depreciation, of a perceived amenity to the community in general. One way of adjusting the balance is to reduce local-authority rates and land taxes proportionately. If this is not done at the administrative level the courts may do it on appeal. In 1991 Brisbane's stately Queensland Club won a large reduction in its land taxes in that way. In the following year the owners of an inner-Brisbane building erected in 1882 had their valuation, for rating purposes, reduced from $\$ 1,500,000$ to $\$ 300,000$. If the High Court adheres to a narrow view of 'acquisition', it would be well within federal powers to institute a predictable scheme of tax concessions, bounties or grants to redress the sterilising effects of environmental and other fashionable interventions.

The points raised in this article are highlighted by recent applications of 'Aboriginal heritage' laws in the Northern Territory and South Australia. It is widely known that the Mabo 'native title' doctrine does not apply to freehold lands or to Crown lands devoted to public purposes. It is not nearly so well known that these limitations do not apply to ministerial decrees under native 'heritage' laws. A substantial portion of a freehold residential block in Alice Springs has been 'sterilised' to protect a recently discovered sacred site (The Australian, 10 April 1995, p.12). Much more spectacular is the Hindmarsh Island bridge affair, in which a ministerial order issued under the Aboriginal and Torres Strait Islander Heritage Protection Act may result in losses to the contractors of $\$ 50 \mathrm{~m}$, with consequential losses to local businesses and property owners that could be as high as $\$ 175 \mathrm{~m}$ (The Courier Mail, 27 May 1995, p.34). In the latter case, if the courts eventually decide that Aboriginal Affairs Minister Robert Tickner has exceeded his powers, compensation may be payable; but otherwise, as the constitutional exegesis stands, the Commonwealth can deny that any 'acquisition' has occurred.

\section{References}

Moens, G. \& J. Trone, 'Is There an Implied Constitutional Right of Freedom of Communication?', Agenda 1(1): 71-9.

Walters, J. (1994), 'Tightening the Screws on "Takings", Govenuing 7(11): 18-20. 